\title{
Transformação radical, mobilização total e natureza: alguns aspectos tão essenciais quanto negligenciados do éros segundo Platão
}

\author{
PEDRO LUZ BARATIERI *
}

\begin{abstract}
RESUMO O artigo demonstra quatro importantes pontos a respeito dos $\mathrm{D} i$ álogos. Depois de mostrar que (1) Platão compreende a experiência filosófica mais elevada como a consumação da experiência erótica, passa a descrever três traços que parecem tão essenciais a essa experiência tal como Platão a entende quanto comumente negligenciados pelas leituras mais comuns. Conquanto esses atributos não esgotem a essência do éros platônico e não se pretenda, assim, dar-lhe uma definição, são atributos que é preciso destacar a fim de entender por que o filósofo pode compreender a experiência filosófica mais elevada como a consumação da experiência erótica. O primeiro desses traços é (2) o condão do éros de ocasionar uma transformação radical, já que, conforme passagem do Fedro (265a-b), o éros é uma loucura divina que nos retira dos hábitos convencionais. O segundo aspecto a ser demonstrado é (3) como o éros caracteriza-se, sobretudo de acordo, ainda, com o Fedro (251b-d), como uma mobilização total: é a experiência em que todas as partes da alma, inclusive a parte racional, são pela primeira vez despertadas em conjunto. Já o terceiro e último traço essencial do éros aqui demonstrado é (4) o fato de a mobilização total que o constitui ser a mobilização da natureza (phusis) de cada um.
\end{abstract}

PALAVRAS-ChaVe Platão; Éros; Transformação; Mobilização; Natureza.

* Doutorando UFRJ - PPGF

Bolsista CNPQ 


\section{INTRODUÇÃO}

Certa feita um excelente professor explicava a filosofia do jovem Nietzsche. Em tom assaz apologético, explanava que, segundo esse filósofo, a vida de todo ser vivo, inclusive do homem, reduzir-se-ia a um processo de nascimento, envelhecimento e morte desprovido de qualquer sentido: em última instância e de um ponto de vista amoral, ergo além do bem e do mal, os homens, de tão frágeis, efêmeros e insignificantes, não passariam de meras "folhas que caem", arrematava o profundo mestre citando Homero. Aqui não nos importa tanto a correção ou não dessa leitura; importa, antes, que mal o professor terminara de falar, um jovem algo nervoso tomou a palavra e disse:

- Que absurdo tu estás dizendo, pois se não houvesse desenvolvimento pleno, florescimento e frutificação, sequer haveria o nascimento! Nem é preciso entender a teoria platônica do éros pra levar isso em conta: basta lembrar-se da própria mãe - e quem não teve uma? - ou então do júbilo e da superabundância da experiência erótica e sexual!

Visivelmente incomodado, depois de ajeitar os óculos e respirar fundo, o professor respondeu:

- Primeiro, não me tuteies: “professor”. Depois...

- Mas - disse o colega interrompendo o mestre - Santo Agostinho tuteava Deus!

Ao que o docente respondeu, com um sorriso no canto da boca e certo ar de deboche:

- Me desculpa, mas tu não és Santo Agostinho, meu caro.

Encarando altivamente o professor e acentuando o "tu”, o aluno retrucou:

- Tampouco tu és Deus.

Embora logo em seguida a aula tenha terminado e a discussão morrido ali, dado que então eu já estudava Platão, fiquei curioso com a alusão ao filósofo e fui perguntar ao colega o que queria dizer com aquilo. Mal sabia eu que iria despertar, com a minha simples pergunta, um vulcão cuja erupção ainda inspira, anos depois, a feitura de 
minha tese de doutorado. É que o colega desandou a discursar, quase gritando, por horas a fio, sempre com os olhos arregalados obscenamente encarando-me e com um entusiasmo bizarro que se manifestava da cabeça aos pés: "Mas isso é o cerne da filosofia platônica, meu caro, o cerne! A experiência do Ser, to on, como a Plenitude! Daí que todas as descrições que os Diálogos dão do conhecimento mais elevado, ou seja, do Ser, sejam feitas em termos eróticos: trata-se, afinal, de um orgasmo psíquico, de um gozo místico! Se o éros, de um lado, é falta, a presença de uma ausência, o Ser, de outro, é a presença plena, a não falta, a Plenitude!”. Tomado de curiosidade, escutei-lhe, primeiro, o comentário acerca das referidas passagens, depois, o relato do que teria sido o seu próprio “gozo místico" - para falar como nosso amigo -, relato no final do qual o orador estava tão fora de si e emocionado - de fato, lágrimas jorravam-lhe dos olhos - que parecia estar repetindo a experiência relatada.

Em face disso, pode-se notar que o assunto em questão, ensejando ainda debates tão acalorados e envolvendo uma questão de tal monta como o sentido da vida, está longe de importar "apenas” exegeticamente e tem, a rigor, uma relevância no que concerne às nossas vidas hic et nunc.

\section{A CONTEMPLAÇÃo OU EXPERIÊNCIA DO SER COMO CONSUMAÇÃO DA EXPERIÊNCIA ERÓTICA}

A propósito, voltando-me para a questão exegética, cumpre dizer que, logo depois desse encontro um tanto estranho, fui reler as passagens dos Diálogos que o colega me apontara à luz do que dissera. Constatei, de fato, que pelo menos a República (49ob), o Banquete (205d) e o Fedro (251e) contêm passagens que apontam para algo como uma relação erótico-sexual, no mínimo certa mistura de um orgasmo com um parto, para falar da relação mais elevada entre o amante da sabedoria e o Ser. Algumas dessas passagens são as seguintes. República (49ob):

Acaso não seria uma defesa adequada dizermos que aquele que verdadeiramente gosta de saber tem uma disposição natural para lutar pelo Ser [ $\pi \rho \mathbf{\rho} \mathbf{c} \boldsymbol{\tau} \boldsymbol{\tau}$ ò ôv (pros to on)], e não se detém em cada um dos muitos aspectos particulares que existem na aparência, mas prossegue sem defalecer nem desistir de sua paixão

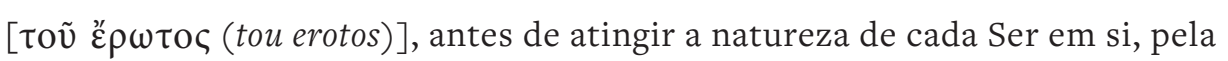
parte da alma à qual é dado atingi-lo - pois a sua origem é a mesma -; depois de se aproximar e de se unir ao verdadeiro Ser $[\mu \iota \gamma \varepsilon i \varsigma$ $\tau \tilde{\omega}$ ő $v \tau \iota$ ő $v \tau \omega \varsigma$ (migeis

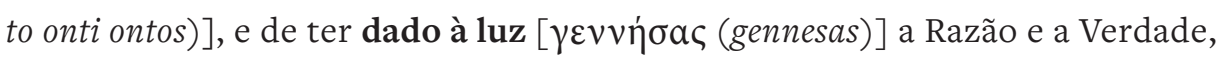


poderá alcançar o saber e viver e alimentar-se de verdade, e assim cessar seu sofrimento; antes disso, não? (Trad. Maria Helena R.Pereira. Destaque meu.)

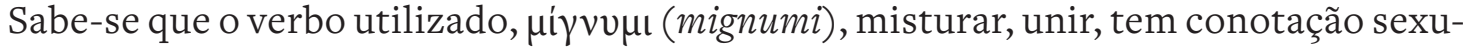
al e significa também o intercurso sexual ${ }^{1}$. Já no Banquete (205d), Sócrates se vale da experiência erótica para caracterizar toda criação espiritual e, sobretudo, a própria filosofia:

[...] sempre que o poder fecundante se aproxima do que é belo, fica jovial e expansivo no seu regozijo, e concebe e procria. Porém, quando se trata de algo feio, retrai-se aflito e triste, recolhe-se em si mesmo e afasta-se sem gerar, levando consigo o fardo incômoda da semente. É o que explica o alvoroço inefável do ser fecundo e transbordante de seiva diante da beleza, pois esta o alivia do grande sofrimento da geração. (Trad. C. A. Nunes ${ }^{2}$ )

Convém notar que essa euporia no contato direto (suneinai) com o belo depois transforma-se na geração de discursos (209c) e, por fim, no dar à luz a virtude verdadeira (212a). "Suneinai", aliás, é usado tanto para intercurso sexual (206c6) quanto para o contato com o Belo mesmo (212a2). É digno de nota, outrossim, que no contexto do auge dos mistérios contemplativos Diotima abandone a liguagem visual e passe a falar em contato direto.

O Fedro (251e), por sua vez, também aponta para algo do gênero:

Ao percebê-lo [o amante ao amado], aspirando o desejo em largos haustos abre o que antes estava obstruído, e tomando novamente fôlego, deixa de sentir as agulhadas e as dores, passando, daí em diante a fruir do mais delicioso prazer

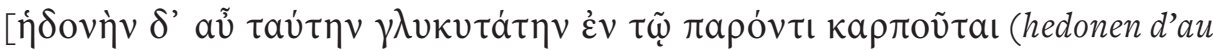
tatuten glukutaten en to paronti karpoutai)]. (Trad. C. A. Nunes ${ }^{3}$ )

À luz disso, parece oportuno destacar três aspectos do éros platônico que julgo serem tão essenciais quanto frequentemente negligenciados em favor de outros mais evidentes à primeira vista. Deve-se ter em mente, porém, que não pretendo com isso dar uma definição do referido conceito, tampouco negar a relevância dos aspectos

1 Cf. verbete $\mu$ i $\gamma v v \mu$ em LIDDELL, H. G. \& SCOTT, R., 2010, p.512: "B. Pass. [...] 4. to have intercourse

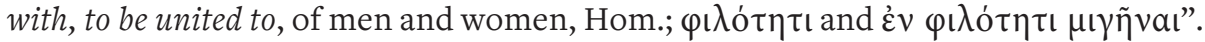

2 Salvo aviso em contrário, toda tradução do Banquete será de Carlos Alberto Nunes.

3 Salvo aviso em contrário, toda tradução do Fedro será de Carlos Alberto Nunes. 
mais notórios do éros, como ser um desejo (epithumia) e, eo ipso, falta (endeia), bem como ser um poder mediador (metaxu) entre o humano e o divino ${ }^{4}$. Apenas destaco os aspectos que destaco porque, ademais da mencionada negligência, parecem-me sobremodo importantes para entendermos por que Platão pode compreender a experiência filosófica mais profunda como uma consumação da experiência erótica 5 .

\section{O ÉROS COMO TRANSFORMAÇÃO RADICAL}

a primeira característica essencial do éros platônico a ser aqui exposta é seu condão de ocasionar uma transformação radical, ou seja, desde a raiz, no amante. De fato, no diálogo Fedro, depois de escutar a crítica de Lísias aos apaixonados e fazer ele próprio sua crítica ao amor, Sócrates profere seu belo discurso sobre a natureza da alma humana para, agora, elogiar o Éros. Se para muitos a paixão (éros) é digna de censura porque os amantes se tornam irracionais e loucos, Sócrates argumenta que, não obstante também comportarem a perda da racionalidade, diversas outras experiências de delírio são estimadas em altíssima medida pelos gregos, como a possessão das sacerdotisas oraculares por Apolo, a dos poetas pelas Musas e aquela dos ritos purificatórios por Dioniso. Como se vê, argumenta Sócrates, os maiores bens vieram-nos pela loucura, particularmente a loucura divina. O Éros seria a mais benéfica das loucuras divinas:

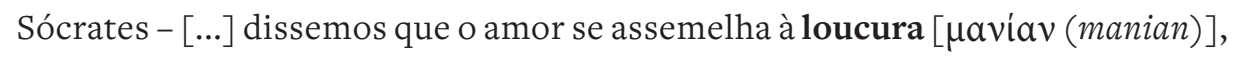
não é isso mesmo?

Fedro - Sem tirar nem pôr.

Sócrates - Mas, há dois gêneros de loucura: a produzida por doenças humanas

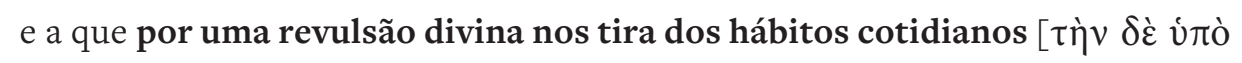

4 Tampouco negligencio outros aspectos menos notórios do éros platônico, como seu caráter poético (dado que é uma geração ou poiesis em beleza), a atopia e a desmedida ou hubris (ambas podendo ser constatadas no caso do referido colega, que ultrapassou os limites de seu lugar de aluno) ligadas ao éros.

5 A essas passagens de descrições eróticas do contato com o Ser, Kahn (1996, p.274) acrescenta passagem do Fedon em que Sócrates diz que o amante (erastes!) da sabedoria deveria estar pronto para morrer, da mesma forma que outros homens quiseram morrer por suas mulheres e seus amados (68a-b). Esse mesmo autor acresce o seguinte acerca dessas passagens: "As with religious mystics down through the ages, Plato's experience of intellectual contact with his transcendent Entities is so powerful that only the language of sexual union seems adequate to give it expression". KAHN, 1996, p.275. 


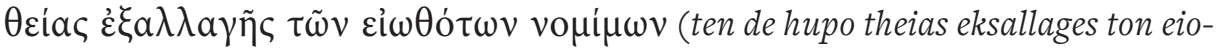
thoton nomimon)].

Fedro - Perfeitamente.

Sócrates - Na loucura divina distinguimos quatro espécies, referentes a quatro divindades: [...] e a quarta, a erótica, considerada a melhor de todas, a Afrodite e Eros. (Fedro, 265a-b; destaque meu)

Ou seja, o Éros, porquanto uma loucura ou possessão divina, arrancar-nos-ia das convenções costumeiras; daí não ser estranho que muitos o reprovem pela falta de bom senso dos amantes e apaixonados - afinal, estão tomados por uma divindade e, ipso facto, fora de si.

Ademais disso, Sócrates argumenta que o éros é a melhor das loucuras divinas porque enseja a reconquista das asas da alma, perdidas quando houve sua queda do lugar supracelestial. Conforme o mito que conta no Fedro, antes de encarnarem, as almas humanas seriam aladas. Elas seriam como uma biga alada, tendo um cocheiro na direção de dois cavalos. Como, porém, em contraste com as almas divinas, as quais teriam apenas cavalos bons, as humanas teriam um cavalo ruim além do bom, por graça desse cavalo ruim, que representa os apetites irracionais, as almas humanas só a muito custo teriam permanecido no alto e teriam, enfim, caído e perdido suas asas ao entrarem num corpo. O éros seria tão especial precisamente porque equivaleria ao processo de reconquista das asas da alma, que assim poderá voltar ao lugar supracelestial donde caíra antes de encarnar. Vejamos como, ao narrar o surgimento dessa paixão, Sócrates de fato relata uma metamorfose quase tão radical como a de uma lagarta que virasse borboleta (ou, claro, cigarra):

A sua vista [i.e., do amado] é acometido de todo o cortejo dos calafrios: muda $[\mu \varepsilon \tau \alpha \beta o \lambda \eta \dot{~(m e t a b o l e)] ~ d e ~ c o r, ~ t r a n s p i r a ~ e ~ s e n t e ~ u m ~ c a l o r ~ i n u s i t a d o ~[a ̉ n ่ \theta \eta ऽ ~(a e-~}$ thes)]. Apenas recebe por intermédio dos olhos eflúvios da Beleza, irrigam-se-lhe as asas e ele volta a inflamar-se. Com o aquecimento derrete-se o invólucro dos germes das asas, que, endurecido havia muito pela secura, os impedia de brotar, e com o afluxo do alimento entumesce a haste da asa e tende a lançar

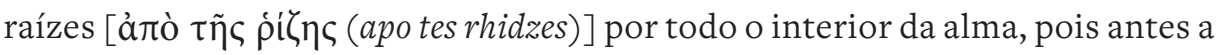
alma era recoberta de plumas. (Fedro, 251a-b)

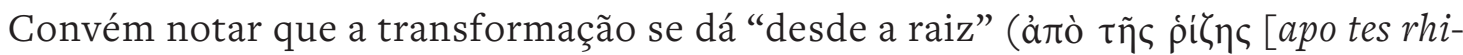
dzes]); é, por conseguinte, radical (do lat. radix, radicis). 
Essas seriam as passagens centrais a fim de demonstrar de modo mais direto a primeira característica essencial do éros escolhida pelo artigo. Pode-se, no entanto, destacar como esse aspecto encontra ressonância ou se desdobra, ainda que de forma indireta, em vários outros elementos importantes dos Diálogos.

Tome-se, p. ex., a noção caríssima a Platão de teoria (theoría). Como bem mostrou Nightingale (2009), na famosa imagem da caverna, Platão, apropriando-se do sentido corrente de "theoria", descreve a filosofia como uma peregrinação ou viagem por parte de uma embaixada cívica para observar eventos divinos. Dado que, assim como a da República, a maioria das theoriai, i.e., peregrinações ou viagens com fins de assistir a eventos religiosos ou festivos, eram embaixadas oficiais custeadas pelo Estado, o theoros teria a obrigação cívica de retornar a sua cidade e relatar a seus concidadãos o que vira e aprendera no exterior. Amiúde acontecia, porém, que nesse retorno o viajante encontrasse diversos problemas, sobretudo porque, ao expandir o seu horizonte e poder, assim, relativizar ou colocar em perspectiva os valores aos quais aderia antes de modo ingênuo, retornava radicalmente modificado. Em Heródoto (IV, 76) há o caso do theorós que ao retornar introduz uma nova divindade na sua cidade e é condenado à morte por isso. Já na imagem da caverna, Platão enfatiza como o filósofo que "viaja" para o exterior da caverna tem, ao retornar, de passar por um longo processo de refamiliarização com as sombras, sob pena de não saber mais lidar com as questões mais práticas e comezinhas, ser objeto de escárnio por parte da maioria e, no limite, vir a ser assassinado como ocorreu com Sócrates ${ }^{6}$. Não há dúvida: isso só ocorre porque o filósofo passa por uma transformação radical, mais ou menos como aquela pela qual, lendariamente ou não, teriam passado os poetas (como Homero e Demódoco, que eram cegos): despertos, por um lado, para o divino e sagrado, fulminados, por outro, pela intensa luz da Verdade, teriam perdido a visão das coisas terrenas e cotidianas em favor de um saber do divino e maravilhoso ${ }^{7}$.

Ademais desses, outros pontos em que se pode vislumbrar uma ressonância da transformação radical que caracteriza o éros seriam os seguintes. Naquilo que há nos $D i$ álogos que poderíamos descrever como “espiritualidade”, com tal que se entenda o

6 Para uma leitura da imagem da caverna que atribui uma centralidade a esse problema da familiaridade com as sombras, cf. BUTTI DE LIMA, 2017.

7 Sobre a intensa relação do poeta e do filósofo com o sagrado (assim em Platão como em Hölderlin), cf. excelente exposição em ENGLER, 2014, esp. pp.198-199. 
termo no sentido em que Foucault ${ }^{8}$ o utilizou ao caracterizar a maior parte das filosofias antigas em contraste com as modernas, que seriam saberes de método. A espiritualidade seria formada pelo conjunto das práticas necessárias para provocar uma mudança substancial no sujeito enquanto sujeito, ou seja, em sua estrutura de sujeito, de modo a torná-lo um novo tipo de ser, agora capaz, porém, de atingir a Verdade. Em contraste com isso, o pensamento moderno seria dominado pelo método, uma vez que pressuporia que todos os seres humanos já seriam capazes de atingir a verdade tais como são, sem precisar passar por transformações radicais e necessitando apenas do método correto. Nesse sentido, o éros desempenharia, no pensamento platônico, o papel de força motriz das transformações necessárias para atingir a Verdade; desempenharia, portanto, o papel da espiritualidade.

A meu ver, é assim que pode ser entendido o que Sócrates exigia de Cálicles e de Alcibíades, bem como o que aconteceu com Platão em seu encontro com Sócrates. De fato, quando o filósofo defendeu que seria melhor sofrer que cometer uma injustiça (Górgias, 469c-b), Cálicles reagiu com escárnio, mas também com espanto, diante da ideia tão invulgar e contraintuitiva: então, argumentou ele, nossas vidas estariam todas de cabeça para baixo. Ao que Sócrates retrucou mais ou menos o seguinte: sim, é isso mesmo, razão pela qual é preciso uma reviravolta da alma, uma conversão praticamente religiosa, ou seja, uma transformação radical, se quisermos viver da melhor forma possível. Foi justamente isso, ao menos de modo mais constante e duradouro, que faltou a Alcibíades (Banquete, 216a-b). Ainda que esse jovem promissor tivesse, de fato, arroubos de caráter erótico, filosófico e algo religioso quando escutava Sócrates e se envergonhava da vida que levava, tais modificações não eram radicais o suficiente para detê-lo na senda do saber e da virtude. Faltou-lhe deixar de ser apenas o amado e passar a ser um amante de fato, como ele próprio testemunha a respeito do que Sócrates causava em seus jovens amigos; em outras palavras, faltou-lhe a força (éros) necessária para mudar radicalmente de vida tornando-se ele próprio agente de sua formação e não mero receptáculo passivo de informações ou doutrinas ${ }^{9}$. Diante disso, pode-se considerar que a anedota ${ }^{10}$ segundo a qual Platão teria queimado suas

8 FOUCAULT, 2006, p.19.

9 “Seria bom, Agatão [...] se com a sabedoria acontecesse isso mesmo: pela simples ação de contato, passar de quem tem muito para quem está vazio [...]”. Banquete, 175d.

10 Diógenes Laércio, III, 5. 
tragédias quando conheceu Sócrates simbolizaria a ideia de que na origem da filosofia estaria um acontecimento de transformação radical, ou seja, uma experiência intensa a tal ponto que desencadeia uma mudança da vida como um todo e não apenas a disposição de adquirir ensinamentos teóricos.

Em face do sobredito, entende-se que o éros possa ser considerado um páthos (Fedro

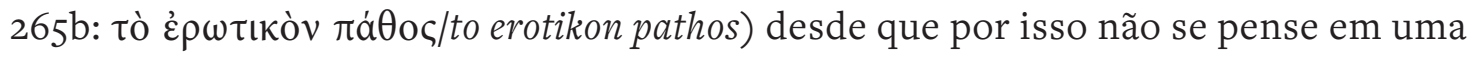
emoção ou sentimento de ordem subjetiva, mas sim em uma experiência, algo que implica, pois, uma saída (ex-) dos limites ou do perímetro (-peri) habitual e por isso comporta sempre, além de algum perigo, uma transformação radical ${ }^{11}$.

\section{O ÉROS COMO MOBILIZAÇÃO TOTAL ${ }^{12}$}

Essencialmente relacionada com a primeira característica está a segunda, pois tal transformação radical só ocorre, ao que parece, porque o éros também é uma mobilização total - afinal, ninguém "viaja” senão de corpo inteiro ${ }^{13}$. É também no Fedro que isso aparece de modo mais translúcido, dado que quando Sócrates descreve o crescimento das asas da alma, dá uma forte ênfase à ideia de totalidade: “Com o afluir do alimento, o talo da plumagem engrossa e ganha impulso para crescer, desde a raiz,

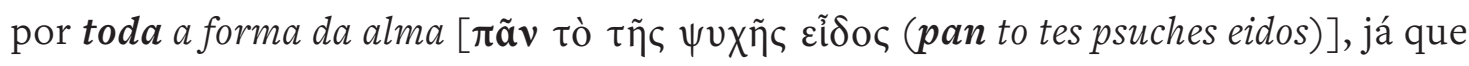
toda $[\pi \tilde{\alpha} \sigma \alpha($ pasa) ] ela era alada antigamente" (251b5-7). Nesse processo, “toda [ö $\lambda \eta$ (hole)] ela ferve e brota" (251c1), e assim a alma, "espicaçada por todas [ $\pi \tilde{a} \sigma a(p a s a)$ ] as partes, inquieta-se e angustia-se" (251d5) (destaque meu). Depois, essa mobilização total parece ser condição da perfeição, no sentido do plenamente realizado, ao qual nada falta, do amante filósofo: “Apenas o homem que fizer recto uso de tais recordações, o perpetuamente iniciado em mistérios perfeitos, apenas esse se torna na

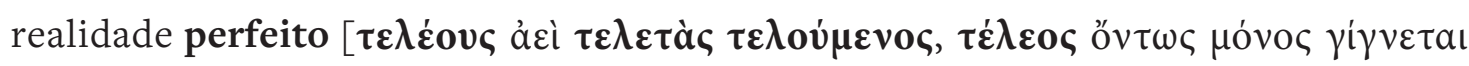
(teleous aei teletas teloumenos teleos ontos monos gignetai)]" (249c6-8; destaque meu).

11 A propósito dessa transformação radical, em sua interpretação do éros platônico, Charles Kahn tece comentários que claramente corroboram essa ideia, pois fala no comprometimento com a filosofia, para Platão, como algo comparável a uma conversão religiosa: "Isso envolve uma reestruturação da personalidade em seus valores e prioridades, o tipo de transformação psíquica que os místidos do Oriente chamam iluminação" (trad. minha). KAHN, 1996, p.273. Autor também fala, a esse respeito, em uma "total transformation of the personality". Ibid., p. 274.

$12 \mathrm{O}$ nome aqui usado foi retirado do título de um ensaio de Ernst Jünger.

13 Cf. acima (p.5) relação entre "theoría" e viagem. 
Daí não parecer nenhum disparate o que disse nosso amigo, conforme mencionado no início, quanto a Platão entender a experiência do Ser como a experiência da plenitude, ou seja, da presença e da satisfação plena, da não falta, em contraposição ao éros, que seria falta ${ }^{14}$.

Realmente, antes de surgirem as asas, a alma detinha três partes distintas - (1) o cocheiro ou a razão, (2) o cavalo bom ou a parte emotiva e (3) o cavalo mau ou a parte apetitiva -, cada qual restrita a seu âmbito e modo de ser, sem nada que fosse de uma parte a outra e as unisse. As asas da alma, no entanto, crescem pela alma toda, portanto inclusive pela razão. Passa destarte a haver algo que mobiliza pela primeira vez a alma inteira em conjunto, quase como se agora fosse algo indivisível. É algo digno de se questionar, aliás, como se daria isso: acaso seria despertado algo para além das três partes, algo indivisível e no que residiria a verdadeira personalidade, por assim dizer, do amante, ou seria antes o caso que apenas as três partes da alma seriam mobilizadas todas elas para o mesmo fim? A princípio, a imagem do Fedro parece sugerir que os dois cavalos são necessários para a ascensão da alma: o éros seria fundamental porque, além de ensejar o crescimento das asas, teria força suficiente para sublimar os outros impulsos, o desejo sexual e o desejo de honra, redirecionando-os, mas não os anulando, para “cima”, de modo que a força dos dois cavalos seria aproveitada e eles seriam sempre necessários. Mas sê-lo-iam também quando a alma já está, por assim dizer, voando? Assim, uma passagem do final da República (X, 611b-612a) parece sugerir que a verdadeira essência da alma seria indivisível e que suas divisões - a parte que deseja comida, p. ex. - só nos pareceriam evidentes em razão de sua mistura com o corpo; nesse caso, pode ser que o éros seja equivalente ao despertar desse verdadeiro e indivisível “eu”, por assim dizer, algo diferente das três partes da alma e da harmonia entre elas.

De qualquer modo, já se pode entender uma das razões pelas quais, da perspectiva platônica, o éros seria imprescindível para a verdadeira paideia ${ }^{15}$ : só por meio da mobilização total que lhe seria peculiar dar-se-ia uma reviravolta da alma que fosse não

14 Comparar o amor como falta e desejo do não-presente (me paróntos) e de o que-não-é (ho me éstin) em Banquete, 200e, com o gozo (hedonen glykytáten karpoûtai) no presente (en to parónti) em Fedro, 251e.

15 República, 403a-c: “[...] nossa discussão acerca da música está terminada (telos)? Acabou (teteleuteken) onde devia (dei teleutan). Pois a música deve acabar (teleutan) no amor do belo (eis ta tou kalou erotika)". Vale lembrar que telos não é fim cronológico nem utilitário. 
apenas da razão mas da alma toda, tal como requer a definição de educação que dá Sócrates no livro VII da República ${ }^{16}$. A educação da razão, portanto, não seria suficiente, tampouco a "simples" curiosidade intelectual; requer-se o despertar da personalidade como um todo e um engajamento transformardor em um novo modo de vida, com novos desejos, novos hábitos e novos valores. O éros cumpre esse papel essencial ${ }^{17}$.

Note-se, assim, como ele está intimamente relacionado com o modo como Platão entende a atividade filosófica. De forma que já nos parece um tanto alheia, Platão, a exemplo da maior parte dos filósofos antigos, concebe a filosofia como uma atividade altamente pessoal e não como “mera” profissão. O filósofo não teria uma profissão entre outras e viveria o resto do seu tempo como todos os demais, com os mesmos valores, costumes, gostos e desejos. Desta feita, filosofar não seria uma capacidade entre outras, posta em prática quando se quer, como são as capacidades pelas quais cada um é o que (mas não quem) é e exerce uma profissão. Da perspectiva platônica, filosofa-se sempre por amor - e como isso não nos soa pleonástico? - e como pessoa; à maneira socrática, filosofa-se com a cara descoberta e de pés descalços como no encontro mais casual.

Como se vê, essa mobilização total que caracteriza o amor platônico está diretamente relacionada às modificações que compõem a referida transformação radical. Uma das mais importantes é que tudo de que se ocupava o amante - família, bens, honrarias etc. - e que antes era cheio de sentido para ele, de algum modo perde o sentido, e ele só consegue pensar no que ama, doravante aquilo em virtude do que (telos) ele existe e, portanto, o eixo irradiador a partir do qual todo o resto - inclusive ele mesmo - adquirirá algum significado ou não ${ }^{18}$. Por isso

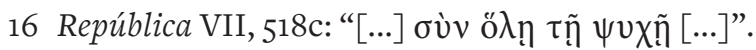

17 Ainda que formulada em termos diferentes e usada de outra perspectiva, também a ideia de uma mobilização total parece desempenhar importante papel na interpretação que Kahn dá do éros platônico, pois esse estudioso acredita que o éros absorveria, resolvendo-lhe os problemas, o intelectualismo socrático na metafísica platônica, porquanto envolveria um saber que já conteria uma transformação de toda a estrutura psíquica e, pois, força motivacional suficiente para acarretar determinadas ações. KAHN, 1996, esp. p.263 e p.273. Em outras palavras, porque o éros é uma transformação radical que envolve uma mobilização de toda a alma, o conhecimento ensejado por ele já implicaria desejos e ações com ele consonantes, de tal modo que o intelectualismo socrático seria assim preservado e de algum modo resolvido.

18 Fedro, 252a: amante não faz caso de ninguém mais que do belo, esquecendo-se (lelestai, de lantháno) de mãe, irmãos e todos os companheiros, além de descurar de toda sua riqueza (ousia) e da etiqueta. 
sói acontecer aos amantes o "romper com o mundo" e "jogar tudo fora" 19 Como se vê, aí também reside um dos grandes perigos do amor, pois caso houver a perda do amado - tanto mais provável quanto mais efêmero for -, haverá a perda de todo significado ou sentido da existência, incluindo uma crise profunda de identidade $^{2 \circ}$. Assim, Santo Agostinho, lembrando a ocasião da perda do melhor amigo, perda essa que o tornou um problema para si mesmo, sentenciou: "Era desgraçado, e desgraçada é toda alma presa pelo amor às coisas mortais”, já que agora um tédio profundo - ou seja, a indiferença total e a perda de qualquer sentido - dominava-lhe a vida $^{21}$. O que é amado, por sua presença e brilho, oculta e faz esquecer o resto; daí até equacionarmos a incapacidade de esquecer (lantháno) com a incapacidade de deixar de amar e, portanto, o recordar - i.e., o trazer de volta (re-) ao coração (cor, cordis) com o amar.

De resto, é porque o amor é essa mobilização total que acaba determinando o caráter inteiro de cada um ${ }^{22}$, ademais de ter o condão especial de revelar quem se é (e não somente o quê se é). Ocorre que essa mobilização total não é outra coisa senão a phusis, i.e., o despertar e vir a ser de quem se é.

\section{O ÉROS COMO A NATUREZA (PHUSIS)}

Assim, a última característica do éros platônico a ser aqui destacada é a proximidade, se não identidade, entre ele e a natureza ${ }^{23}$. Poderíamos dizer que no caso do éros se

Cf. a diferença entre os para-quês e o em virtude de em Ser e Tempo (parágr.18, p. ex.), bem como a diferença entre o a fim de (in order to) e a utilidade, de um lado, e o em razão de (for the sake of) e o significado, de outro, em A Condição Humana, parágr. 21. O amor determina o em virtude de ou o significado.

19 Como diz Eu te amo, de Chico Buarque: “Ah, se já perdemos a noção da hora/ Se juntos já jogamos tudo fora/ Me conta agora como hei de partir/ Se, ao te conhecer, dei pra sonhar, fiz tantos desvarios/ Rompi com o mundo, queimei meus navios/ Me diz pra onde é que inda posso ir". BUARQUE, 1980. Ênfase minha.

20 Como diz o poema Maresia, de Antônio Cícero: “O meu amor me deixou/ Levou minha identidade/ Não sei mais bem onde estou/ Nem onde a realidade”.

21 Confissões, IV, 6.

22 República: o tirano (573a-c), amante dos prazeres do baixo-ventre, o amante do lucro, o amante de honras e vitórias e o filósofo, que ama a sabedoria e a razão (581a-c).

23 Nesse ponto específico, Leo Strauss é raro exemplo de estudioso que parece ter dado algum peso a essa relação e, portanto, alguém cujas considerações podem corroborar a leitura exposta a seguir. Cf. Strauss (2001, p.10), em que autor equaciona o éros platônico à natureza humana (ainda que 
trata da mobilização total da natureza, ou até que a natureza, enquanto nascimento ou vir-a-ser - pois phusis é o substantivo ligado ao ver phuomai, brotar, nascer - é exatamente essa mesma mobilização total. Aliás, se a ideia de movimento está implicada na de mobilização total, a natureza (phusis) enquanto nascimento ou vir-a-ser expressa bem esse aspecto motriz do éros. Pode-se pensar, relacionado a isso, o éros como um pathos no sentido de emoção, tradução que ressalta, pelo aspecto motriz implicado no termo neolatino (do lat. motus, movimento, e emoveo, mover para fora), a ideia de movimento implicada em geral no termo pathos, diferente de "paixão" (do lat. patior, padecer, sofrer), que sublinharia o elemento de passividade inerente à ideia de pathos (do gr. paskho, padecer, sofrer, experimentar etc.).

No Fedro, há toda uma ênfase na natureza, no nascer e no brotar das asas da alma: a beleza irriga a natureza das asas (tô̂ pterô̂ physis), então derrete-se o que trancava o germe (ekphysin) das asas e impediam-no de brotar (blastánein); com essa nutrição (trophes), a asa ganha impulso para eclodir (phyesthai) desde a raiz, quando toda a alma ferve e brota (anakekiei), o que dá certa irritação: como quando nascem (phyosin) os dentes, assim também com o nascer das asas (pterophyein) (251b-c). Depois, é nessa experiência que se descobre (e se realiza) a natureza de cada qual, como se se é por natureza filósofo (ei philósophos [...] tèn physin) (252e3). Não é de se estranhar a importância da natureza na palinódia, já que um dos seus propósitos era determinar a natureza da alma (psykhês physeos) divina e humana; e a conclusão que se pode tirar a esse respeito, parece-me, é que o Amor é a physis das almas humanas. Não por acaso, depois, quando o diálogo adquire um caráter mais técnico e menos religioso, a natureza substituirá a inspiração (amorosa) no que concerne às condições necessárias para tornar-se um orador perfeito (269d).

Outrossim, no Banquete a natureza também tem papel precípuo na questão do amor: “quando chega a idade (helikia)", diz Diotima, "a nossa natureza (physis) tem vontade de procriar (tíktein)”, e isso no fundo é amor: uma geração em beleza (206c-e). Levando em conta ainda que Diotima chegará ao ponto de dizer que cada indivíduo, seja no corpo, seja na alma, só permanece o mesmo durante sua vida por constantemente reproduzir-se (207d-208a), bem como que o éros seria a força motriz dessa constante

pré-política e irracional) e, em certo sentido, à natureza do todo, bem como depois (p.196), em que afirma que o éros é a natureza da natureza, porquanto o coração do vir-a-ser. 
reprodução ou geração em beleza, não seria disparatado concluir que, para Diotima, o éros, se não for essa própria natureza enquanto constante geração e vir a ser, no mínimo teria o importante papel de força positiva e criativa - em contraposição à morte, ao esquecimento e à desintegração - da phusis.

Depois, também no que concerne à República a natureza está vinculada sobretudo ao polo "subjetivo" da experiência do Ser, ou seja, é aquilo que se realiza plenamente no ser humano que tem essa experiência: cada membro da cidade ideal só pode realizar a tarefa para a qual está mais apto por natureza, mas o que garante essa adequação à natureza e, portanto, a perfeição da cidade ideal é o fato do seu rei ser também um filósofo, ou seja, ser alguém que tem a experiência do Ser. Nesse mesmo diálogo também parece possível dizer que cada natureza tem o amor que lhe é próprio, o que reitera a proximidade entre essas duas ideias: o tirano por natureza é o amante dos prazeres do baixo-ventre (573a-c), o plutocrata é o amante do lucro, o timocrata ama as honras e vitórias e o filósofo ama a sabedoria e a razão (581a-c).

\section{CONCLUSÕES}

À luz de tudo que se mostrou acima, algumas conclusões podem ser tiradas. Viu-se, com efeito, que a experiência filosófica mais elevada é compreendida, nos Diálogos, como a consumação - ou a entelecheia, para usar belíssima palavra de Aristóteles - da experiência erótica. Diante disso, torna-se mais fácil perceber que a temática do éros não se restringe a diálogos como o Banquete e o Fedro, como poderia parecer a muitos, bem como torna-se compreensível por que, a rigor, o éros é praticamente onipresente nos Diálogos. No Cármides, v. g., o éros está no horizonte de discussão da temperança, como indica o momento de excitação e temperança de Sócrates ao ver o jovem (154cd). Já no Lísis, é um problema erótico que dá azo ao diálogo, na verdade uma lição de arte erótica por parte de Sócrates a Hipotales (206c). No Eutidemo, por sua vez, é Ctesipo, jovem ainda demasiado impetuoso, que recebe aulas de como agir com seu amado (273a). Seria ocioso destacar a presença desse tema nos Amantes Rivais. Já no Alcibíades Maior é a temática erótica que anima o diálogo desde o início, dado que Sócrates se apresenta a Alcibíades na condição de seu apaixonado (103a-104c). Essa mesma relação desempenha papel fundamental, conquanto subestimado pelos estudiosos, no Protágoras (309a-c). No tocante ao Górgias, nele o éros e o amor são relevantes assim no problema dos desejos sem limite do tirano do qual a vida é enal- 
tecida pelos interlocutores de Sócrates (492c, p. ex.) como nas preferências pessoais de Cálicles e Sócrates (481d). Tampouco do Mênon o amor deixa de se fazer presente (7ob e 76b-c). Outrossim, o Teages é um dos diálogos, ademais do Banquete, em que Sócrates se apresenta como especialista em erótica (128b). Enfim, não há como superestimar a relevância do éros para os Diálogos e agora entendemos melhor o porquê disso: a experiência filosófica mais elevada é compreendida como a consumação da experiência erótica.

Segue-se disso que o éros também precisa ser compreendido à luz dessa consumação, o que implica destacar-lhe os aspectos que, se bem que em geral sejam negligenciados, são importantes para esclarecer como está relacionado com aquela experiência. Cumpre destacar, nesse sentido, que o éros não é apenas falta, mas, como se viu, é também uma transformação radical por meio de uma mobilização total da natureza. Assim passamos a sublinhar alguns elementos "euporéticos”, por assim dizer, do éros, já que ele também é filho de Riqueza (Poros). Mostrou-se, então, como o éros acarreta pela primeira vez uma mobilização de todas as partes da alma, e como todas elas, inclusive a razão, são assim erotizadas. Constatou-se, depois, que essa mobilização que caracteriza o éros está intimamente relacionada com a natureza (phusis) no sentido do vir a ser plenamente de alguém. Torna-se patente, assim, que aquilo que toda uma tradição posterior - de Aristóteles ${ }^{24}$ a Plotino ${ }^{25}$ e Dante, ${ }^{26}$ passando por Agostinho ${ }^{27}$ e Tomás de Aquino - dirá do amor como a tendência natural de cada

24 Cf., p.ex., De Anima, II, 4, 215a, onde Aristóteles parece praticamente parafrasear Diotima: "O mais natural dos atos (physikotaton ergon)", diz o Estagirita a respeito de tudo que tem vida, “é produzir outro ser igual a si mesmo [...] a fim de que participem (metekhosin) do eterno (aei) e do divino como podem; pois todos desejam isto e em vista disto fazem tudo o que fazem por natureza [...]".

25 Plotino, Enéada III. 4 (Sobre o Amor, em Tratados das Enéadas, Polar Editorial, 2000, p.107): “Esse amor [eros] das almas individuais é o daimon que acompanha cada indivíduo. É ele que inspira os desejos que são conformes à natureza [kata physin] de cada Alma e cada Alma gera um amor correspondente ao seu mérito e à sua essência”. Ainda que essa tradução tenha problemas e Plotino pareça colocar a questão em forma de pergunta, no fim, ao que me parece, ele responde a questão de modo afirmativo.

26 No centro do Purgatório (XVIII, 16-75), ou seja, no coração do poema inteiro, Virgílio dá uma grande lição sobre o amor a Dante: como o fogo naturalmente sobe para o lugar mais de acordo com sua forma e matéria naturais, assim o ânimo sente desejo (disire), que é movimento espiritual, e não cessa (posa) até que a coisa amada o faça gozar (gioire). Cf. MAZZEO, 1957.

27 Confissões, XIII, 9: “O corpo, devido ao peso, tende para o lugar que lhe é próprio, porque o peso não tende só para baixo, mas também para o lugar que lhe é próprio. Assim o fogo encaminha-se para cima, e a pedra para baixo. Movem-se segundo o seu peso. Dirigem-se para o lugar que lhes compe- 
ente ir para o lugar que lhe é próprio de algum modo ecoará as reflexões platônicas sobre o tema.

Ainda assim, a conclusão que me parece mais relevante é que Platão nos ensina, dentre outras coisas, que, ao contrário do que pretendia o profundo mestre citado no início, não somos apenas folhas que caem: podemos crescer, desenvolvermo-nos plenamente, florescer e dar frutos ${ }^{28}$, algo para o que o próprio Homero já apontava, embora a ênfase dada, o uso que se faz das passagens e o clima em que são postas ocultem-no, deixando-o passar despercebido:

As gerações dos mortais assemelham-se às folhas das árvores, que, umas, os ventos atiram no solo, sem vida; outras, brotam na primavera, de novo, por toda a floresta viçosa $\left(\theta^{\prime}\right.$ '̈ $\lambda \eta$

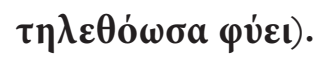

Desaparecem ou nascem os homens da mesma maneira ${ }^{29}$.

[...] por causa dos homens, apenas, que semelhantes às folhas das árvores, ora se expandem

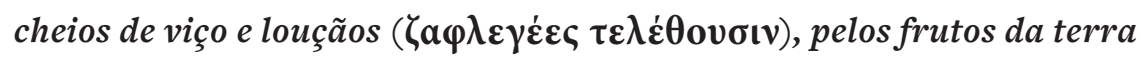
nutridos, ora da vida privados, sem brilho nenhum emurchecem ${ }^{30}$.

te. [...] As coisas que não estão no próprio lugar agitam-se, mas, quando o encontram, ordenam-se e repousam. O meu amor é o meu peso. Para qualquer parte que vá, é ele quem me leva”.

28 "Eros e il desiderio", comenta Mauro Bonazzi, renomado helenista italiano, a propósito da doutrina platônica, "sono sempre legati alla morte. Sono la forza che opponiamo al potere distruttore della morte, esprimono la nostra volontà di mostrare che non siamo stati semplici foglie che si sono staccate da un ramo $[\ldots] ”$... BONAZZI, 2015, p.2.

29 Ilíada, VI, v. 146-149. Destaque meu.

30 Ibid., XXI, v. 463-466. Destaque meu. 


\section{REFERÊNCIAS BIBLIOGRÁFICAS:}

AGOSTINHO. Confissões. Os Pensadores. São Paulo: Abril Cultural, 1973.

ALIGHIERI, Dante. A Divina Comédia. Trad. Italo Eugenio Mauro. São Paulo: Editora 34,2014 .

ARENDT, H. A Condição Humana. Rio de Janeiro: Forense Universitária, 2010.

ARISTÓTELES. De Anima. Trad. Maria Cecília Gomes dos Reis. São Paulo: Ed. 34, 2006. BONAZZI, Mauro. Il grande equivoco dell'amore platonico. In: Il dibattito delle idee. Corriere della sera: $20 / 09 / 2015$.

BUARQUE, Chico. Eu te amo. In: Vida (álbum LP). Rio de Janeiro: Polygram/Philips, 1980.

BUTTI DE LIMA, Paulo. La doppia discesa del filosofo. Una lettura politica della caverna platonica. In: La Cultura, n. 1, abril, 2017.

ENGLER, Maicon. Heidegger, Hölderlin e a fundação poética: superação da metafísica e platonismo. In: Revista Peri de Filosofia, v. 06, n. 1, 2014, p.179-210.

FOUCAULT, M. A Hermenêutica do Sujeito. São Paulo: Martins Fontes, 2006.

HEIDEGGER, M. Ser e tempo. Trad. Marcia Sá Cavalcante Schuback. Petrópolis: Vozes, 2009.

HOMERO. Ilíada. Trad. Carlos Alberto Nunes. Rio de Janeiro: Ediouro, 2002.

KAHN, Charles H. Plato and the socratic dialogue: the philosophical use of a literary form. Cambridge University Press, 1996.

LAÉRCIO, Diógenes. Vidas e doutrinas dos filósofos ilustres. Trad. Mário da Gama Kury. Brasília: Editora UNB, 1988.

LIDDELL, H. G. \& SCOTT, R. An intermediate Greek-English Lexicon. Oxford: Benediction Classics, 2010.

MAZZEO, Joseph Anthony. Dante's Conception of Love. Journal of the History of Ideas, Vol. 18, No. 2 (Apr., 1957), pp. 147-160. 
NIGHTINGALE, Andrea Wilson. Spetacles of Truth in Classical Greek Philosophy: Theoria in its cultural context. New York: Cambridge University Press, 2009.

PLATÃO. Platonis Opera, 4 vols. (Org.: John Burnet). Oxford: Clarendon, 2002 (1900). _. Banquete. Trad. de Carlos Alberto Nunes. Belém: EDUFPA, 2011.

_. Fedro. Trad. de Carlos Alberto Nunes. Belém: EDUFPA, 2011.

— Górgias. Lisboa: Edições 70.

—. República. Trad. de Maria Helena da Rocha Pereira. Lisboa: Fundação Calouste Gulbenkian, 2001.

PLOTINO. Tratados das Enéadas. São Paulo: Polar Editorial, 2000.

STRAUSS, Leo. On Plato's Symposium. Chicago: The University of Chicago Press, 2001. 